
Radiation Sensitizer RB 6145

Anthony D. Sercel, Vladimir G. Beylin, Mark E. Marlatt, Boguslawa Leja, and

H. D. Hollis Showalter*,\#

Chemistry Department and Chemical Research \& Development, Pfizer Global Research and Development, Michigan Laboratories, Ann Arbor, MI 48105

André Michel ${ }^{\S}$

Chemistry Department, Université de Sherbrooke, Sherbrooke (Québec), Canada J1K 2R1

Received March 2, 2006

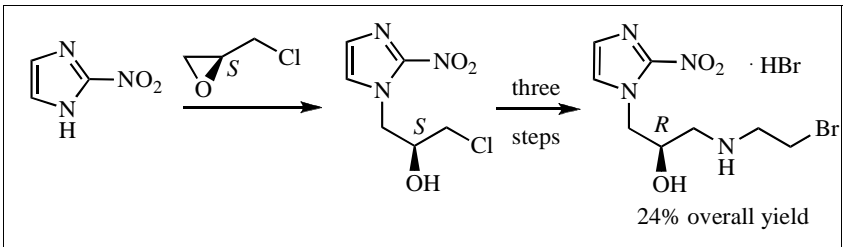

Short, efficient pathways are described for the synthesis of racemic 2-nitroimidazole radiation sensitizer RB-6145 (2a) and each of its corresponding $(R)$ - and $(S)$-enantiomers (2b and 2c, respectively). The synthesis of each enantiomer commences with the appropriate chiral epichlorohydrin and utilizes a novel application of 3-trimethylsilyl-2-oxazolidinone (3b) as a mild, safe surrogate for highly toxic aziridine. The synthesis of the $(R)$-enantiomer $(\mathbf{2} \mathbf{b})$ has been successfully scaled up to provide multi-kilo quantities of material for early stage preclinical evaluation.

J. Heterocyclic Chem., 43, 1597 (2006).

Introduction.

Radiation sensitizers represent an enticing concept in tumour therapy. The objective of directed radiation along with a co-administrated sensitizing agent is to achieve a maximum effect on tumour tissue, while minimizing the damage to normal tissues. Many tumours are characterized by a lower oxygen pressure relative to normal tissue, resulting in the formation of clusters of hypoxic cells in response to reduced oxygen diffusion. These hypoxic cells pose a challenge in radiation therapy as they are markedly more radio-resistant than oxic (normal) cells [1]. Therefore, various chemical agents, including radiation sensitizers, tissue protectors, and chemotherapeutic agents, have been sought in order to selectively enhance the effect of radiation therapy on these relatively radio-resistant cells [2].

Amongst many classes of drugs designed as radiation sensitizers, the nitroimidazoles have been one of the most extensively studied. These include metronidazole [3], misonidazole [4] (Fig. 1), and more recently bifunctional 2-nitroimidazole derivatives, possessing alkylating functionality, capable of anti-angiogenic activity [5] or depletion of endogenous non-protein thiols (NPSH) such as reduced glutathione [6]. These effects have been found to play a crucial function in determining the response of cells to several types of radiation. Amongst the bifunctional 2-nitroimidazoles, RSU-1069 (1a), with an aziridine moiety in the side chain, has been shown to have a high differential toxicity toward hypoxic cells compared to oxic cells under in vitro and in vivo experimental conditions. However, in the clinic it caused severe emesis and had to be withdrawn [7].<smiles>Cc1ncc([N+](=O)[O-])n1CCO</smiles>

metronidazole<smiles>O=[N+]([O-])c1nccn1CC(O)CN1CC1</smiles>

1 b: $(R)$ a: $(R, S) ; \mathrm{RSU}-1069$
b: $(R)$<smiles>COCC(O)Cn1ccnc1[N+](=O)[O-]</smiles>

misonidazole<smiles>O=[N+]([O-])c1nccn1CC(O)CNCCBr</smiles>

2

a: $(R, S)$; RB-6145

b: $(R) ; \mathrm{PD}-144872$

c: $(S) ; \mathrm{PD}-144871$
Figure 1

Described herein is a short, scaleable synthesis (Scheme 1) of RB-6145 (2a), a prodrug of 1a that is better tolerated systemically in mice than RSU-1069 [7-9]. We were also interested in whether the chirality of $\mathbf{2 a}$ was important under in vitro/in vivo experimental conditions with respect to both efficacy and systemic toxicity. To address this question, we have developed an efficient, scaleable synthesis of the $(R)$ - and $(S)$ - enantiomers $2 \mathbf{b}$ (PD-144872) and 2c (PD-144871), respectively, of 2a utilizing epi- 

and A. Michel

chlorohydrin as a chiral scaffold. Preliminary accounts of the synthesis of the enantiomers $\mathbf{2 b}$ and $\mathbf{2 c}$ have already been reported from our laboratories [10,11]. This paper provides detail on the strategy utilized to approach the large-scale synthesis of these compounds (Scheme 2), and also discusses numerous approaches, some unsuccessful, that ultimately led to their successful synthesis. Additionally, this paper provides comprehensive analytical and spectroscopic information, absent in earlier reports, for all compounds of the synthesis outlined in Scheme 3.

Results and Discussion.

Scale-up synthesis of RB-6145 (2a). As our initial biological studies required the availability of multi-gram quantities of racemic RB-6145 (2a), we targeted a route that would be short, efficient, and potentially applicable to the synthesis of each enantiomer at a later stage. The route that we developed is shown in Scheme 1 and represents a modest improvement over a similar process reported by Suto in the patent literature [12]. Thus, a tetrahydrofuran suspension of the sodium salt of 2-oxazolidinone (3a) was condensed with epibromohydrin at $60^{\circ}$ to provide epoxy-oxazolidinone 4 in $74 \%$ yield following distillation. The use of catalytic tetra- $n$-butylammonium iodide was important to the success of this reaction. Subsequent epoxide opening of $\mathbf{4}$ with 2-nitroimidazole (5) in warm ethanol, utilizing cesium carbonate as base, provided the racemic alcohol $\mathbf{6 a}$ in $85 \%$ isolated yield. Ring opening of the oxazolidinone moiety then proceeded uneventfully with $31 \%$ hydrogen bromide in acetic acid under similar conditions described earlier by Suto et al. [8] to provide highly pure RB-6145

\section{Scheme $1^{a}$}

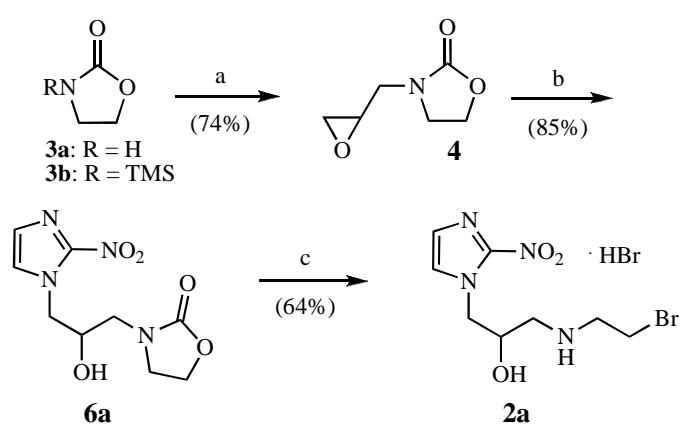

(a) 3a, NaH, tetra- $n$-butylammonium iodide, THF, $60^{\circ} \mathrm{C}, 17 \mathrm{~h}$; (b) 2-nitroimidazole (5), $\mathrm{Cs}_{2} \mathrm{CO}_{3}$, abs EtOH, $85^{\circ} \mathrm{C}, 4 \mathrm{~h}$; (c) $31 \% \mathrm{HBr} / \mathrm{HOAc}, 25^{\circ} \mathrm{C}$, $23.5 \mathrm{~h}$.

(2a) in $64 \%$ yield. The overall yield of the 3-step sequence shown in Scheme 1 was $40 \%$ and the process was readily scaleable.

Strategies toward the synthesis of the $(R)$ - and $(S)$ enantiomers of RB-6145. Following initial favourable biological evaluation of RB-6145 (2a) [7-9], it was necessary to synthesize each of its corresponding enantionmers as part of an early preclinical development campaign. As was the case for racemic compound, it was mandatory to develop a short, efficient, and economical route that would provide the multi-gram quantities required for advanced efficacy and early stage toxicology studies. Our strategy for synthesizing enantiomers $\mathbf{2 b}$ and $\mathbf{2 c}$ is shown in Scheme 2 (one enantiomer of $\mathbf{7}$ shown for convenience). We visualized the use of generalized chiral scaffold 7 (chiral glycidyl arenesulfonate or epichlorohydrin), which would react with one or both of two chosen nucleophiles with high regioselectivity (path a or b) to provide a route to a single enantiomer (either $\mathbf{2 b}$ or 2c). Having developed this, we would then employ the opposite antipode of $\mathbf{7}$ to access the opposite enantiomer. Based on our requirements for route development, each enantiomer of chosen scaffold 7 would have to be commercially available, reasonably priced, and easy to handle under scaleable reaction conditions. We also required that our chosen reagent would provide a high level (ca. $95 \%$ ee) of regioselectivity in the first step.

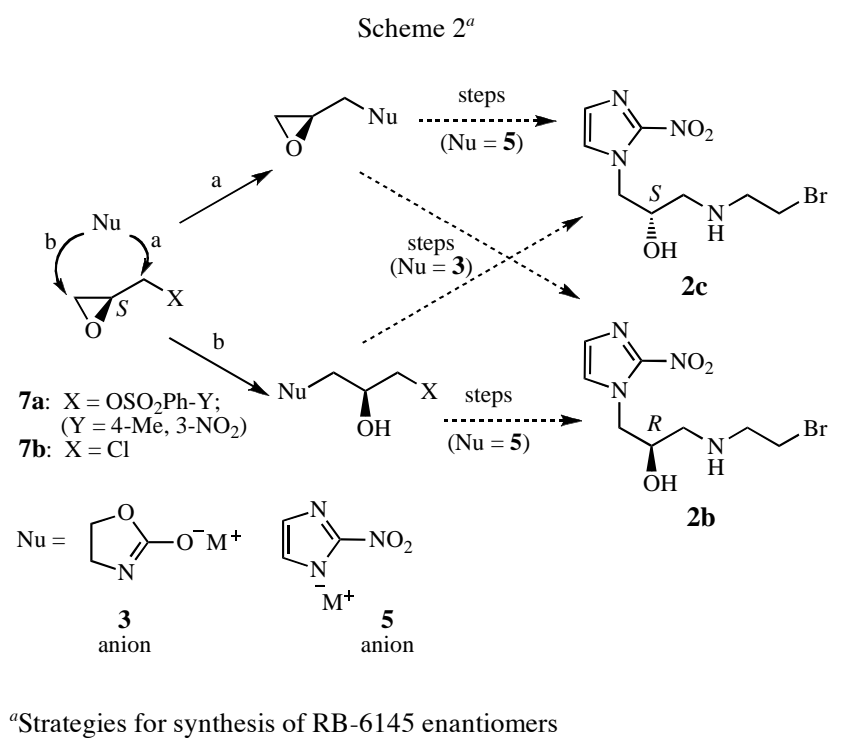

Trials with chiral glycidyl arenesulfonates. Aiming to take advantage of the route developed in Scheme 1, we directed our initial focus to securing intermediate $\mathbf{4}$ in chiral form. Based on the prior work of Sharpless et al. [13] on nucleophilic openings of chiral glycidyl arenesulfonates, we expected that reaction via path a of Scheme 2 would predominate. Toward this end, we evaluated the reaction of a number of salts (sodium, lithium, tetra- $n$-butylammonium) of 3a with two chiral glycidyl arenesulfonates $\left(\mathbf{7 a} ; \mathrm{Y}=4-\mathrm{CH}_{3}, 3-\mathrm{NO}_{2}\right)$. Thus, reaction was evaluated in polar solvents, including $N, N$ dimethylformamide and acetonitrile, as well as the less 
polar solvent tetrahydrofuran. The resultant product 4 was then reacted with 2-nitroimidazole (5) to provide $\mathbf{6}$, which was derivitized to a mixture of diastereomeric urethanes with $(R)-(+)-\alpha$-methylbenzyl isocyanate [14] for assay by C-8 HPLC. The results of several trials revealed that optimal conditions were to react the sodium or tetra- $n$ butylammonium salt of 3a with glycidyl 3-nitrobenezenesulfonate $\left(\mathbf{7 a}, \mathrm{Y}=3-\mathrm{NO}_{2}\right)$ in warm tetrahydrofuran. This led to a relatively slow, complete conversion to $\mathbf{6}$ in $\mathrm{ca}$. $60 \%$ yield. C-8 HPLC of the urethane derivatives showed that under these, as well as other conditions, there was always a ca. 85:15 mixture of diastereomers (corresponding to $70 \%$ ee), indicating that nucleophilic attack had not proceeded with the high level of required regioselectivity. Similarly, reaction of the cesium salt of 2-nitroimidazole (5) with $\mathbf{7 a}\left(\mathrm{Y}=3-\mathrm{NO}_{2}\right)$ in $\mathrm{N}, \mathrm{N}$ dimethylformamide resulted in a slightly higher, but still unacceptable, optical purity $(76 \%$ ee). This led us to abandon further work with glycidyl arenesulfonates as a chiral scaffold.

Trials with chiral epichlorohydrin. Development of a practical synthesis of the $R$ - and $S$-enantiomers of RB-6145. We next directed our attention to epichlorohydrin $\mathbf{7 b}$ as a chiral scaffold (Scheme 2, $\mathrm{X}=\mathrm{Cl}$ ). Our initial studies examined the reaction of the sodium salt of 2-oxazolidinone (3a) with $\mathbf{7 b}$ in tetrahydrofuran. However, in contrast to the similar reaction on racemic epibromohydrin shown in Scheme 1, we experienced difficulty in isolating chemically pure epoxyoxazolidinone $\mathbf{4}$ as it tended to decompose during distillation, or attempted purification by silica gel or alumina column chromatography. Furthermore, reaction of purified 4 with 2-nitroimidazole (5) under optimum conditions, followed by C-8 HPLC assay as described above, revealed that alcohol $\mathbf{6}$ was of unacceptable optical purity. This signified that attack of nucleophile 3a was again occurring via both pathways of Scheme 2. We then directed our attention to 2-nitroimidazole anion as the nucleophile. This led to a successful, scaleable synthesis of 2b (PD-144872) and 2c (PD-144871). Scheme 3 shows the route developed for the $(R)$-enantiomer $\mathbf{2 b}$. Although there was prior literature regarding reaction of nitroimidazoles with racemic epichlorohydrin [15], reaction with chiral reagent had been virtually unexplored. However, considerable precedent with other nucleophiles [16] suggested that we might be able to achieve high regioselectivity via nucleophilic attack onto the epoxide moiety of $\mathbf{7 b}$ via path $\mathbf{b}$ of Scheme 2. Employing the conditions of Kawamura et al. [16b], reaction of 2nitroimidazole (5) with neat $(S)$-epichlorohydrin (7b), catalyzed by tetramethylammonium chloride, resulted in a clean conversion to product $\mathbf{8}$ in $60 \%$ isolated yield and $96 \%$ ee. While this met our optical purity criteria, we desired scale-up conditions wherein we could use closer to stoichiometric quantities of $\mathbf{7 b}$. After evaluating a number of different solvent and base combinations, we found that reaction of the cesium salt of $\mathbf{5}$ with 1.3 equivalents of $\mathbf{7 b}$ in refluxing ethanol led to a $74 \%$ yield of crude chlorohydrin $\mathbf{8}$, which was of sufficient chemical purity to carry on directly to epoxide 9. Thus, rapid

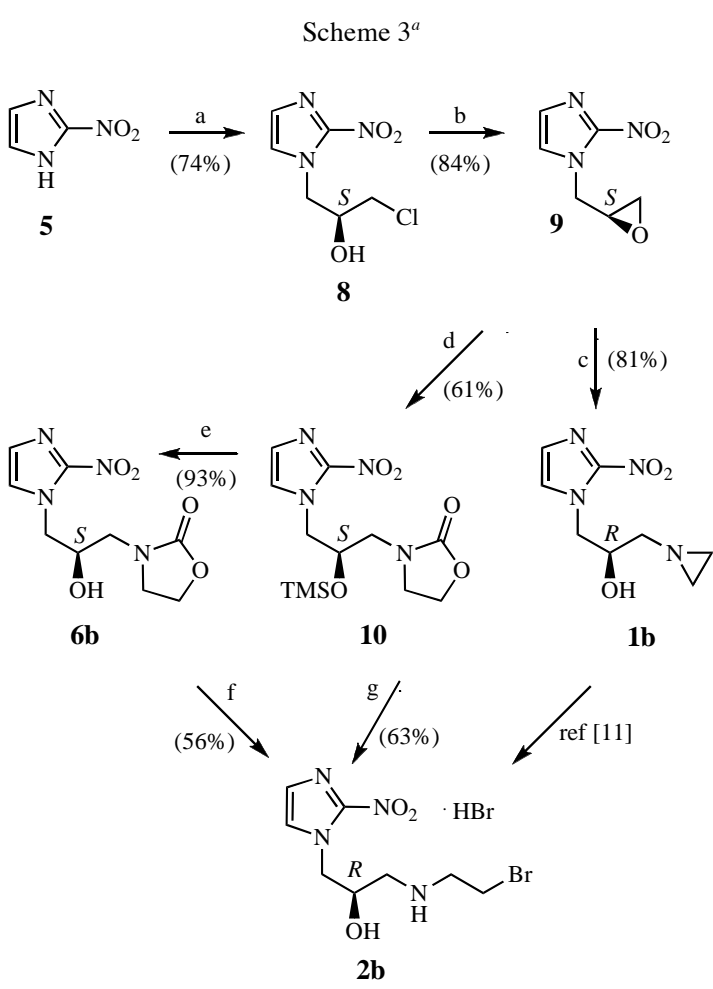

${ }^{a}$ (a) (S)-epichlorohydrin (7b), $\mathrm{Cs}_{2} \mathrm{CO}_{3}$, abs EtOH, reflux, $2 \mathrm{~h}$; (b) 1:1 $10 \%$ aq $\mathrm{NaOH}: \mathrm{CH}_{2} \mathrm{Cl}_{2}, 0-5{ }^{\circ} \mathrm{C}, 7.5 \mathrm{~h}$; (c) aziridine, 99:1 (v/v) EtOH: $\mathrm{NEt}_{3}$, reflux, $30 \mathrm{~min}$; (d) 3-trimethylsilyl-2-oxazolidinone (3b), KOTMS, $95{ }^{\circ} \mathrm{C}, 1.5 \mathrm{~h}$; (e) $1: 1 \mathrm{MeOH}: H O A c, 25{ }^{\circ} \mathrm{C}, 16 \mathrm{~h}$; (f) $31 \%$ $\mathrm{HBr} / \mathrm{HOAc}$, reflux, $25^{\circ} \mathrm{C}, 7 \mathrm{~d}$; (g) $31 \% \mathrm{HBr} / \mathrm{HOAc}, 25^{\circ} \mathrm{C}, 23.5-$ $47.5 \mathrm{~h}$.

stirring of $\mathbf{8}$ in a cold biphasic mixture of $10 \%$ sodium hydroxide in dichloromethane provided 9 in $84 \%$ isolated yield, and $94 \%$ ee following a single crystallization from tert-butyl methyl ether. With 9 now in hand, we had the option of completing the synthesis of $\mathbf{2} \mathbf{b}$ by one of two routes. The shorter of the two would proceed via precedented chemistry utilizing aziridine, followed by ring opening with hydrogen bromide [11]. We demonstrated the feasibility of this on a modest scale by reaction of 9 with aziridine in refluxing 1\% triethylamine in ethanol. This led to an $81 \%$ yield of $\mathbf{1 b}$ that was $100 \%$ optically pure. However, the high toxicity of aziridine necessitated the development of an alternative route to 2 

and A. Michel

utilizing 2-oxazolidinone as an aziridine surrogate. Accordingly, we first developed conditions for the addition of 3a to the racemate of epoxide 9 [17]. The optimum conditions were to conduct the condensation with 5 equivalents of $\mathbf{3 a}$ and 0.05 equivalents of cesium carbonate in tert-butanol at $80{ }^{\circ} \mathrm{C}$. The reaction proceeded in $60 \%$ yield and was driven to completion by precipitation of racemic product 6a. However, application of these conditions to chiral compound 9 resulted in a complex mixture containing starting material. We ascribe this to the greater solubility in the reaction medium of chiral product $\mathbf{6 b}$ due to its different physical properties (see discussion below). This precluded precipitation of the product as it formed, allowing known side reactions, resulting from displacement of the nitro group by intermediate alkoxide, to set in [8]. To circumvent this, we reasoned we would need conditions allowing the nascent alkoxide to be trapped following nucleophilic attack of 3a onto chiral 9. Trimethylsilyl was deemed to be ideal for this, and toward this end we looked at 3-trimethylsilyl-2-oxazolidinone (3b), described in the literature principally as a silylating agent [18], to supply both the aziridine surrogate and protecting group requirements. Thus, we set up trials with 5 equivalents of the reagent in tetrahydrofuran and examined different bases (potassium fluoride, cesium fluoride, tetra- $n$-butylammonium fluoride) to catalyze the $N$-desilylation. Tetra- $n$-butylammonium fluoride as base afforded desired product $\mathbf{1 0}$ with excellent optical purity ( $\geq 96 \%$ ee). However, yields were generally low and product purification was difficult. Toward developing scaleable conditions, we reasoned that potassium trimethylsilanolate [19] might be a superior base as the product (hexamethyldisiloxane) of 3-trimethylsilyl-2oxazolidinone desilyation could also function as a silyl donor for the nascent alkoxide and then be recycled as reformed base. Indeed, hexamethyldisiloxane has previously been reported as a silylation reagent for alcohols [20]. In practice, this worked quite well. Thus, treating a hot solution of 1.2 equivalents of 3trimethylsilyl-2-oxazolidinone $\mathbf{( 3 b )}$ and 1 mole $\%$ potassium trimethylsilanolate with epoxide $\mathbf{9}$ in tetrahydrofuran led cleanly to $97 \%$ optically pure $(94 \%$ ee) $\mathbf{1 0}$ in a reproducible and scaleable yield of $\mathrm{ca}$. $60 \%$. Having developed this key transformation, the remaining steps proceeded uneventfully. Treatment of $\mathbf{1 0}$ under mild acidic desilyating conditions (1:1 methanol:acetic acid) provided $\mathbf{6 b}$ in $93 \%$ yield, which could then be parlayed onto target compound $\mathbf{2} \mathbf{b}$ by the conditions $(31 \%$ hydrogen bromide in acetic acid) described above in Scheme 1. For purposes of scale-up, we found that $\mathbf{2 b}$ could be secured directly from silyloxy intermediate $\mathbf{1 0}$ in $63 \%$ by applying these same reaction conditions, thus eliminating one step. Final product, $\mathbf{2 b}$, obtained by the shortened sequence was $99 \%$ and $100 \%$ pure by analytical and chiral HPLC, respectively. The structure and stereochemistry of $\mathbf{2 b}$ was confirmed by single crystal Xray analysis [21]. The overall yield of $\mathbf{2} \mathbf{b}$ obtained by the four-step sequence shown in Scheme 3 was $24 \%$, and the route was scaled up to $\leq 3 \mathrm{~kg}$ of product without a yield reduction.

Starting from $(R)$-epichlorohydrin, the entire sequence outlined in Scheme 3 was repeated to provide the chemically and optically pure $(S)$-enantiomer of RB-6145 (2c) in comparable overall yield.

As mentioned above, the enantiomers of compounds of Scheme 3 display markedly different physical properties from their racemates (where direct comparisons can be made). For example, the melting point of racemic alcohol 6a is $216-218{ }^{\circ} \mathrm{C}$ [8] as compared to $134-136{ }^{\circ} \mathrm{C}$ for $\mathbf{6 b}$. We also observed different solubilities for these compounds in common organic solvents, with each enantiomer showing greater solubility. Such differences can be ascribed to molecules of one enantiomer having a greater affinity for those of its opposite enantiomer than for their own kind. Such a pairing leads to a true "racemic compound", which has a lower enthalpy than that of either pure enantiomer [22].

\section{Conclusions.}

We have developed short, efficient pathways for the synthesis of racemic 2-nitroimidazole radiation sensitizer RB-6145 (2a) and each of its corresponding enantiomers $(\mathbf{2 b}, \mathbf{2 c})$. The route to racemic compound incorporates an improved procedure to make multi-gram quantities of key epoxy-oxazolidone intermediate 4. The synthesis of each enantiomer was successfully completed after an extensive campaign to evaluate glycidyl arenesulfonates and epichlorohydrin as chiral scaffolds. The successful solution utilized chiral epichlorohydrin and resulted in the novel application of 3-trimethylsilyl-2-oxazolidinone (3b) as a mild, safe aziridine surrogate and the use of potassium trimethylsilanoate as a preferred base in the synthesis of key intermediate 10. The synthesis of the $(R)-$ enantiomer (2b) was successfully scaled up to provide multi-kilo quantities of material for early stage preclinical evaluation.

\section{EXPERIMENTAL}

Melting points were taken on a Thomas-Hoover Unimelt capillary melting point apparatus and are uncorrected. Proton and carbon magnetic resonance $\left({ }^{1} \mathrm{H}\right.$ NMR and ${ }^{13} \mathrm{C}$ NMR $)$ spectra were obtained on a Bruker AM-250 spectrometer at $250 \mathrm{MHz}$ and a Bruker AM-300 instrument at $75 \mathrm{MHz}$, respectively. Chemical shifts are reported as $\delta$ values (parts per million) downfield from internal tetramethylsilane. The following abbreviations are used to describe peak patterns when appropriate: $\mathrm{br}=$ broad, $\mathrm{s}=$ singlet, $\mathrm{d}$ 
$=$ doublet, $\mathrm{t}=$ triplet. Mass spectra were obtained either in the electron impact (EIMS) or chemical ionization (CIMS; utilizing $1 \%$ ammonia in methane) mode on a VG Masslab Trio-2A mass spectrometer. Optical rotations were taken on a Perkin-Elmer 241 polarimeter. Combustion analyses were determined on a CEC 440 Elemental Analyzer or by Robertson Microlit Laboratories, Inc., Madison, NJ. Column chromatography was carried out in the flash mode utilizing Merck 230-400 mesh silica gel. Analytical thin layer chromatography (TLC) was carried out on Merck (Kiesegel 60F-254) silica gel plates with detection by UV light. Chemical purity was determined by analytical high pressure liquid chromatography (HPLC) on the following columns: A, Phenomenex Ultracarb C8 column (5 $\mu, 4.6 \mathrm{~mm}$ ID x $250 \mathrm{~mm})$; B, Beckman Ultrasphere ODS column ( $5 \mu, 4.6 \mathrm{~mm}$ ID x $250 \mathrm{~mm})$; C, Beckman Ultrasphere CN column ( $5 \mu, 4.6 \mathrm{~mm}$ ID x $250 \mathrm{~mm})$; mobile phases utilized include (1) x:y methanol : $0.05 M$ aqueous $\mathrm{NH}_{4} \mathrm{H}_{2} \mathrm{PO}_{4}$ buffer, $\mathrm{pH} 4$; (2) x:y acetonitrile : $0.05 M$ aqueous $\mathrm{NH}_{4} \mathrm{H}_{2} \mathrm{PO}_{4}$ buffer, pH 3; (3) x:y methanol : $0.001 \quad M$ octanesulfonic acid, sodium salt, adjusted to $\mathrm{pH} 3$ with $85 \%$ $\mathrm{H}_{3} \mathrm{PO}_{4}$; in the x:y ratios of (a) 45:55; (b) $30: 70$; (c) $20: 80$; (d) 40:60. Optical purity was determined on the following chiral columns: D, Diacel Chiralpak AS column (5 $\mu, 4.6$ mm ID x 250 $\mathrm{mm})$; E, Diacel Chiralpak AS column (10 $\mu, 4.6 \mathrm{~mm}$ ID x 250 $\mathrm{mm})$ precooled and maintained at $10^{\circ}$. Mobile phases utilized include (4) $x: y: z$ hexane:ethanol:diethylamine; in the $x: y: z$ ratios of (e) 90:10:0; (f) 70:30:0.1; (g) 90:10:0.1 The flow rate for all HPLC was $0.5-1.0 \mathrm{~mL} / \mathrm{min}$ with detection at $313 \mathrm{~nm}$. All reaction solvents were reagent grade or distilled-in-glass, and were stored over activated $3 \AA$ (for lower alcohols) or $4 \AA$ molecular sieves. Following normal workup procedures, organic extracts were dried over anhydrous magnesium sulfate prior to concentration. Cesium carbonate was pulverized and dried at 400 ${ }^{\circ} \mathrm{C}$ prior to use. All reactions were run under a positive pressure of nitrogen. 2-Nitroimidazole was purchased from Midori Kagaku Co., Ltd. $S$-(+)- and $R$-(-)-epichlorohydrin were purchased from Daiso Co., Ltd.

\section{$(R, S)$-3-(Oxiranylmethyl)-2-oxazolidinone (4).}

The following represents a modification of a patent procedure [12]: A mechanically stirred $25{ }^{\circ} \mathrm{C}$ suspension of $44.43 \mathrm{~g}(0.5 \mathrm{~mol})$ of 2-oxazolidinone (3a) in $500 \mathrm{~mL}$ of tetrahydrofuran was treated portion-wise with $13.2 \mathrm{~g}(0.55 \mathrm{~mol})$ of sodium hydride (from $22 \mathrm{~g}$ of $60 \%$ oil dispersion, pre-washed with $n$-hexane). The suspension was diluted with an additional $100 \mathrm{~mL}$ of tetrahydrofuran, maintained at $25{ }^{\circ} \mathrm{C}$ for $\mathrm{ca} .30 \mathrm{~min}$, and then heated at $50{ }^{\circ} \mathrm{C}$ for $5 \mathrm{~h}$. To the light gray suspension was added $9.2 \mathrm{~g}(24.9 \mathrm{mmol})$ of tetra$n$-butylammonium iodide followed by $52.4 \mathrm{ml}(0.6 \mathrm{~mol})$ of epibromohydrin. The resultant mixture was heated at $60 \mathrm{C}^{\circ}$ for $17 \mathrm{~h}$ during which reaction progress was monitored by GC (DB wax). The mixture was filtered hot, and the salts were washed extensively with ethyl acetate. The combined filtrates were concentrated to leave $82.5 \mathrm{~g}$ of a light yellow oil. The oil was diluted with a small amount of ethyl acetate and the charge was introduced onto an alumina column (Woelm, activity grade I). The column was eluted with ethyl acetate with $200 \mathrm{~mL}$ fractions collected. Each fraction was assayed by GC, and then the product fractions were pooled and concentrated to an oil that was distilled at $129-130{ }^{\circ} \mathrm{C} / 0.12 \mathrm{~mm}$ (lit. [12] bp $100-120{ }^{\circ} \mathrm{C} / 0.05 \mathrm{~mm}$ ) to give $53.6 \mathrm{~g}(74 \%)$ of 4 as a clear oil, $99.2 \%$ pure by $\mathrm{GC} ;{ }^{1} \mathrm{H} \mathrm{NMR}\left(\mathrm{CDCl}_{3}\right): \delta 4.36(\mathrm{t}, J=8.0 \mathrm{~Hz}$, $2 \mathrm{H}), 3.92-3.58(\mathrm{~m}, 3 \mathrm{H}), 3.20-3.00(\mathrm{~m}, 2 \mathrm{H}), 2.82(\mathrm{t}, J=4.3 \mathrm{~Hz}$,
$1 \mathrm{H}), 2.59$ (dd, $J=4.6 \mathrm{~Hz}, 2.4 \mathrm{~Hz}, 1 \mathrm{H}$ ); EIMS: $m / z$ (relative \%) 144 $\left(66, \mathrm{MH}^{+}\right), 100$ (100), $56(80)$.

Anal. Calcd. for $\mathrm{C}_{6} \mathrm{H}_{9} \mathrm{NO}_{3} \cdot 0.1 \mathrm{H}_{2} \mathrm{O}: \mathrm{C}, 49.72 ; \mathrm{H}, 6.40 ; \mathrm{N}$, 9.66. Found: C, 49.98; H, 6.36; N, 9.38.

$(R, S)$-3-[2-Hydroxy-3-(2-nitro-1H-imidazol-1-yl)propyl]-2-oxazolidinone (6a).

A suspension of $24.9 \mathrm{~g}(0.22 \mathrm{~mol})$ of 2-nitroimidazole (5) and $3.58 \mathrm{~g}(11 \mathrm{mmol})$ of cesium carbonate in $230 \mathrm{~mL}$ of absolute ethanol was mechanically stirred at $65{ }^{\circ} \mathrm{C}$ for $25 \mathrm{~min}$, and then treated with $40.9 \mathrm{~g}(0.282 \mathrm{~mol})$ of 3-(oxiranylmethyl)-2oxazolidinone (4), followed by $110 \mathrm{~mL}$ of additional ethanol. The mixture was stirred at $85{ }^{\circ} \mathrm{C}$ for $4 \mathrm{~h}$, and the resulting suspension was stored at $25{ }^{\circ} \mathrm{C}$ for several hours. The solids were collected by filtration, washed with ethanol and dried to leave $47.8 \mathrm{~g}(85 \%)$ of $\mathbf{6 a}$ as a yellow-gold solid, mp $214-215{ }^{\circ} \mathrm{C}$ (lit. [8] 216-218 ${ }^{\circ} \mathrm{C}$ ), one spot by TLC (elution with 4:1 ethyl acetate:methanol) with spectral properties as previously reported. The product was used directly in the next step.

$(R, S)$ - $\alpha$-[[(2-Bromoethyl)amino]methyl]-2-nitro- $1 H$-imidazole1-ethanol, monohydrobromide (2a).

To a mechanically stirred ice-cold solution of $200 \mathrm{~mL}$ of $31 \%$ hydrogen bromide in acetic acid was added portion-wise $48.2 \mathrm{~g}$ $(0.188 \mathrm{~mol})$ of 3-[2-hydroxy-3-(2-nitro-1H-imidazol-1-yl)propyl]-2-oxazolidinone (4). The solution was diluted with 40 $\mathrm{mL}$ more of $31 \%$ hydrogen bromide, and the ice bath was removed. The viscous solution was stirred at $25{ }^{\circ} \mathrm{C}$ for $23.5 \mathrm{~h}$ during which the product precipitated. The suspension was diluted with $350 \mathrm{~mL}$ of 2-propanol, and the solids were collected, washed well with 2-propanol, and then suspended in $250 \mathrm{~mL}$ of methanol. The stirred suspension was boiled for $c a$. $10 \mathrm{~min}$, and then stored in the refrigerator for $4 \mathrm{~h}$. The solids were collected, washed well with 2-propanol, and dried to give $32.1 \mathrm{~g}(46 \%)$ of $2 \mathbf{a}$ as an off-white solid, mp $167-169{ }^{\circ} \mathrm{C}$ (lit. [8] $159-160^{\circ}$ ); $100 \%$ pure by HPLC (system B3b); The ${ }^{1} \mathrm{H}$ NMR spectrum was identical to that previously reported [8].

Anal. Calcd. for $\mathrm{C}_{8} \mathrm{H}_{13} \mathrm{BrN}_{4} \mathrm{O}_{3} \cdot \mathrm{HBr}$ : C, 25.69; H, 3.77; N, 14.98; $\mathrm{Br}$ (tot), 42.73. Found: C, 25.81; H, 3.73; N, 15.17; Br (tot), 43.03 .

The original filtrate was evaporated to a dark semi-solid that was boiled in methanol to give a nearly complete solution. The suspension was cooled in the refrigerator for several hours, and then the solids were collected by filtration and processed as above to give $10 \mathrm{~g}$ of additional $\mathbf{2 a}, \mathrm{mp} 161-163{ }^{\circ} \mathrm{C}$. The filtrate from this crop was combined with the methanolic filtrate from the first crop, and the solution was refrigerated overnight. The precipitated solids were collected by filtration as above, and then triturated in $50 \mathrm{~mL}$ of hot methanol and further processed as above to give $1.8 \mathrm{~g}$ of $\mathbf{2 a}, \mathrm{mp} 164-166^{\circ} \mathrm{C}$.

The latter crops ( $10 \mathrm{~g}$ and $1.8 \mathrm{~g}$ ) were combined and triturated in $80 \mathrm{~mL}$ of methanol and further processed to give $10.3 \mathrm{~g}$ (15\%) of analytically pure $2 \mathrm{a}, \mathrm{mp} 163-165{ }^{\circ} \mathrm{C}, 99.6 \%$ pure by HPLC. Further processing of the combined filtrates gave an additional $2.3 \mathrm{~g}(3 \%)$ of $\mathbf{2 a}, \mathrm{mp} 164-166{ }^{\circ} \mathrm{C}, 99.6 \%$ pure by HPLC.

(S)- $\alpha$-(Chloromethyl)-2-nitro-1H-imidazole-1-ethanol (8).

A $25{ }^{\circ} \mathrm{C}$ stirred suspension of $75.6 \mathrm{~g}(0.669 \mathrm{~mol})$ of 2nitroimidazole (5), $10.9 \mathrm{~g}$ (33.5 mmol) of cesium carbonate, and 

and A. Michel

1.3 $\mathrm{L}$ of absolute ethanol was treated with $68 \mathrm{~mL}(0.869 \mathrm{~mol})$ of $(S)$-epichlorohydrin $(\mathbf{7 b})$, and the resultant mixture was heated at gentle reflux for $2 \mathrm{~h}$. The hot solution was filtered through a preheated pad of ethanol-moistened Celite, the pad was washed with a little ethanol, and the filtrate $(c a .1 .8 \mathrm{~L})$ was maintained at $-5{ }^{\circ} \mathrm{C}$ for $2.5 \mathrm{~d}$. The precipitate was collected, washed with 200 $\mathrm{mL}$ ethyl acetate:diethyl ether (1:1), and dried to give $49.6 \mathrm{~g}$ $(36 \%)$ of 8 as tan needles, mp $127-129{ }^{\circ} \mathrm{C}, 91.9 \%$ chemically pure by HPLC (system A1a). The mother liquor was concentrated to a solid residue that was suspended in $700 \mathrm{~mL}$ of hot ethanol. The suspension was filtered hot, and then concentrated to $400 \mathrm{ml}$. After cooling overnight, the solids were collected as above to give $35.7 \mathrm{~g}(26 \%)$ of a second crop of $\mathbf{8}$, mp $126-127{ }^{\circ} \mathrm{C}, 94.1 \%$ pure by HPLC. The mother liquor was concentrated to a solid residue that was boiled in ethyl acetate. The hot suspension was filtered through preheated moist Celite. The filtrate was maintained at $25^{\circ} \mathrm{C}$ for $3 \mathrm{~h}$, and then overnight at $0-5{ }^{\circ} \mathrm{C}$. The resultant precipitate was collected as above to provide $16.2 \mathrm{~g}(12 \%)$ of a third crop of $\mathbf{8}, \mathrm{mp} 122-126^{\circ} \mathrm{C}, 92.4 \%$ pure by HPLC. An analytical sample was prepared by dissolving a $9.9 \mathrm{~g}$ sample of second crop material in $195 \mathrm{~mL}$ of boiling ethyl acetate. The solution was treated with charcoal, filtered hot, and maintained at $25^{\circ} \mathrm{C}$ for $16 \mathrm{~h}$, and then at $0-5{ }^{\circ} \mathrm{C}$ for $48 \mathrm{~h}$. The resultant precipitate was processed as above to give $7.45 \mathrm{~g}$ of $8, \mathrm{mp} 128-129{ }^{\circ} \mathrm{C}$ (lit. [11] $153-154{ }^{\circ} \mathrm{C}$ ); $[\alpha]_{\mathrm{D}}{ }^{25}-$ $+2.39^{\circ}\left[\mathrm{c} 1\right.$, methanol]; ${ }^{1} \mathrm{H}$ NMR $\left(\right.$ DMSO- $\left.d_{6}\right): \delta 7.30(\mathrm{~s}, 1 \mathrm{H})$, $7.13(\mathrm{~s}, 1 \mathrm{H}), 4.83(\mathrm{dd}, J=13.6 \mathrm{~Hz}, 3.0 \mathrm{~Hz}, 1 \mathrm{H}), 4.66$ (br s, $1 \mathrm{H}$, $\mathrm{D}_{2} \mathrm{O}$ exchangeable), $4.34(\mathrm{dd}, J=13.6 \mathrm{~Hz}, 8.4 \mathrm{~Hz}, 1 \mathrm{H}), 4.24-$ $4.12(\mathrm{~m}, 1 \mathrm{H}), 3.66-3.50(\mathrm{~m}, 2 \mathrm{H})$; CIMS: $\mathrm{m} / z$ (relative \%) 208 $\left(40,{ }^{37} \mathrm{Cl} \mathrm{MH}^{+}\right), 206\left(100,{ }^{35} \mathrm{Cl} \mathrm{MH}^{+}\right), 114(24)$.

Anal. Calcd. for $\mathrm{C}_{6} \mathrm{H}_{8} \mathrm{ClN}_{3} \mathrm{O}_{3}$ : C, 35.05; H, 3.92; N, 20.44; $\mathrm{Cl}, 17.24$. Found: $\mathrm{C}, 35.03 ; \mathrm{H}, 3.87 ; \mathrm{N}, 20.33 ; \mathrm{Cl}, 17.09$.

$(R)$ - $\alpha$-(Chloromethyl)-2-nitro- $1 H$-imidazole-1-ethanol was obtained in a similar manner from $(R)$-epichlorohydrin; mp 128$129^{\circ} \mathrm{C} ;[\alpha]_{\mathrm{D}}{ }^{25}-2.57^{\circ}[\mathrm{c} 1$, methanol].

\section{(S)-2-Nitro-1-(2-oxiranylmethyl)-1 $H$-imidazole (9).}

To a vigorously stirring ice-cold suspension of $100.5 \mathrm{~g}$ (489 mmol) of $(S)$ - $(\alpha)$-(chloromethyl)-2-nitro-1H-imidazole-1ethanol $(8)$ in $1 \mathrm{~L}$ of dichloromethane was added slowly $1 \mathrm{~L}$ of $10 \%$ aqueous sodium hydroxide. The biphasic mixture was stirred for $7.5 \mathrm{~h}$ at $0-5{ }^{\circ} \mathrm{C}$, and then diluted with $500 \mathrm{~mL}$ each of chloroform and water. The phases were separated and the aqueous phase was extracted 3 times with $200 \mathrm{~mL}$ portions of chloroform. The combined organic phases were dried and concentrated to leave $71.1 \mathrm{~g}$ of a yellow oil that crystallized upon prolonged storage at $0-5{ }^{\circ} \mathrm{C}$. The crystals were collected and dried at $0.05 \mathrm{~mm} / 25^{\circ} \mathrm{C} / 8 \mathrm{~h}$ to give $69.1 \mathrm{~g}(84 \%)$ of $9, \mathrm{mp} 42-$ $43{ }^{\circ} \mathrm{C}, 98.4 \%$ chemically pure by HPLC (system B3d). An analytical sample was prepared by passing a solution of $1.14 \mathrm{~g}$ of 9 in $20 \mathrm{~mL}$ of ethyl acetate over a silica gel column, eluting with 1:1 ethyl acetate:cyclohexane. Pure product fractions were combined and concentrated to a solid that was dissolved in 5:2 hexanes:ethyl acetate. The solution was kept at -5 to $0{ }^{\circ} \mathrm{C}$ for 6 $\mathrm{h}$ and the precipitate was collected, washed with diethyl ether, and dried at $0.025 \mathrm{~mm} / 25{ }^{\circ} \mathrm{C}$ to give $681 \mathrm{mg}$ of 9 as pale yellow crystals, mp $43-44{ }^{\circ} \mathrm{C}$ (lit. [11] 54-55 ${ }^{\circ} \mathrm{C}$ ); $99 \%$ chemically pure and $100 \%$ optically pure (system D4e) by HPLC; $[\alpha]_{\mathrm{D}}^{25}-82.18^{\circ}$ [c1, methanol]; ${ }^{1} \mathrm{H}$ NMR $\left(\mathrm{CDCl}_{3}\right): \delta 7.19(\mathrm{~d}, J=1 \mathrm{~Hz}, 1 \mathrm{H})$, $7.18(\mathrm{~d}, J=1 \mathrm{~Hz}, 1 \mathrm{H}), 5.07(\mathrm{dd}, J=14.6 \mathrm{~Hz}, 2.4 \mathrm{~Hz}, 1 \mathrm{H}), 4.20$ $(\mathrm{dd}, J=14.6 \mathrm{~Hz}, 6.4 \mathrm{~Hz}, 1 \mathrm{H}), 3.47-3.38(\mathrm{~m}, 1 \mathrm{H}), 2.94$ (t, $J=$
$4.2 \mathrm{~Hz}, 1 \mathrm{H}), 2.58(\mathrm{dd}, J=4.5 \mathrm{~Hz}, 2.5 \mathrm{~Hz}, 1 \mathrm{H})$; CIMS: $m / z$ (relative \%) $170\left(100, \mathrm{MH}^{+}\right), 114$ (14).

Anal. Calcd. for $\mathrm{C}_{6} \mathrm{H}_{7} \mathrm{~N}_{3} \mathrm{O}_{3}$ : C, 42.61; H, 4.17; N, 24.84 . Found: C, 42.73; H, 4.09; N, 24.86.

(R)-2-Nitro-1-(2-oxiranylmethyl)- $1 \mathrm{H}$-imidazole was obtained in a similar manner from $(R)-8 ; \mathrm{mp} 43-44{ }^{\circ} \mathrm{C} ;[\alpha]_{\mathrm{D}}^{25}+84.95^{\circ}$ [c1, methanol].

(R)- $\alpha$-(1-Aziridinylmethyl)-2-nitro- $1 H$-imidazole-1-ethanol (1b).

A solution of $7.65 \mathrm{~g}$ (45 mmol) of $(S)$-2-nitro-1-(2oxiranylmethyl)- $1 H$-imidazole (9) in $100 \mathrm{ml}$ of 99:1 (v/v) ethanol:triethylamine was treated with $3.9 \mathrm{~g}(90 \mathrm{mmol})$ of aziridine. The solution was heated at reflux for $10 \mathrm{~min}$, treated with $2 \mathrm{~mL}$ of additional aziridine, and refluxed for another 20 min. The solution was concentrated to one-third volume and placed in the refrigerator. The solids were collected, washed with ice-cold ethanol:triethylamine (99:1), and dried at 40 ${ }^{\circ} \mathrm{C} / 0.02 \mathrm{~mm} / 2 \mathrm{~h}$ to give $7.74 \mathrm{~g}(81 \%)$ of $\mathbf{1 b}, \mathrm{mp} 124-126{ }^{\circ} \mathrm{C}$ (lit. [11] 119.5-121 ${ }^{\circ} \mathrm{C}$ ); $R_{\mathrm{f}}=0.31$ (dichloromethane : ethanol : triethylamine, $85: 14: 0.5)$; 1b was $100 \%$ optically pure by HPLC (system E4g); $[\alpha]_{\mathrm{D}}{ }^{24}-26.9^{\circ}$ [c0.95, chloroform] (lit. [11] $-23.5^{\circ}$ [c1.15, chloroform]); The ${ }^{1} \mathrm{H}$ NMR spectrum was identical to that previously reported [11].

Anal. Calcd. for $\mathrm{C}_{8} \mathrm{H}_{12} \mathrm{~N}_{4} \mathrm{O}_{3}$ : C, 45.28; H, 5.70; N, 26.40. Found: C, 45.46; H, 5.70; N, 26.27.

(S)- $\alpha$-(1-Aziridinylmethyl)-2-nitro- $1 H$-imidazole-1-ethanol (1c) was obtained in a similar manner from $(R)-9 ; \mathrm{mp} 123-125{ }^{\circ} \mathrm{C}$ (lit. [11] $118.5-120{ }^{\circ} \mathrm{C}$ ); $[\alpha]_{\mathrm{D}}{ }^{24}+26.6^{\circ}$ [c0.90, chloroform] (lit. [11] $+21.4^{\circ}[\mathrm{c} 0.98$, chloroform $]$ ).

(S)-3-[3-(2-Nitro-1H-imidazol-1-yl)-2-[(trimethylsilyl)oxy]propyl]-2-oxazolidinone (10).

A vigorously stirring mixture of $40.3 \mathrm{~mL}(256 \mathrm{mmol})$ of 3 trimethylsilyl-2-oxazolidinone $(\mathbf{3 b})$ and $274 \mathrm{mg}(2.1 \mathrm{mmol})$ of potassium trimethylsilanolate under a brisk stream of nitrogen was heated to $95{ }^{\circ} \mathrm{C}$. To the solution was added drop-wise a solution of $36.15 \mathrm{~g} \quad(214 \mathrm{mmol})$ of $(S)$-2-nitro-1-(2oxiranylmethyl)-1 $\mathrm{H}$-imidazole (9) in $26 \mathrm{~mL}$ of tetrahydrofuran followed by a $5 \mathrm{~mL}$ rinse. Addition took place over $c a$. $10 \mathrm{~min}$ and at such a rate that the internal temperature never exceeded $105{ }^{\circ} \mathrm{C}$. The flask was kept open during the entire addition of epoxide and for $15 \mathrm{~min}$ afterwards. After heating at $95{ }^{\circ} \mathrm{C}$ for a total of $1.5 \mathrm{~h}, 3.4 \mathrm{~mL}$ of additional $\mathbf{3 b}$ was added to the solution. The mixture was heated for an additional $1.5 \mathrm{~h}$ and then concentrated to leave an oil that was dissolved in $100 \mathrm{~mL}$ of $2: 1$ ethyl acetate:cyclohexane. The solution was purified by silica gel chromatography, eluting with $c a .5 \mathrm{~L}$ of $2: 1$ ethyl acetate:cyclohexane. Product fractions were combined and concentrated to give $71.45 \mathrm{~g}$ of an oil that solidified on standing. The solids were diluted with $200 \mathrm{~mL}$ of tert-butyl methyl ether, and the suspension was refluxed for $45 \mathrm{~min}$, cooled, and filtered. The solids were collected, washed sparingly with tert-butyl methyl ether and dried to leave $37.18 \mathrm{~g}(53 \%)$ of $\mathbf{1 0}$ as a light yellow solid, mp $98-100{ }^{\circ} \mathrm{C}, 99 \%$ chemically pure (system C2c) and $97 \%$ optically pure (system D4f) by HPLC; $[\alpha]_{\mathrm{D}}{ }^{25}+15.4^{\circ}$ [c1, methanol]; ${ }^{1} \mathrm{H} \mathrm{NMR}\left(\mathrm{CDCl}_{3}\right): \delta 7.30(\mathrm{~d}, J=17 \mathrm{~Hz}, 1 \mathrm{H})$, $7.15(\mathrm{~d}, J=22 \mathrm{~Hz}, 1 \mathrm{H}), 4.85-4.66(\mathrm{~m}, 1 \mathrm{H}), 4.52-4.40(\mathrm{~m}$, $2 \mathrm{H}), 4.35-4.20(\mathrm{~m}, 2 \mathrm{H}), 3.94-3.66(\mathrm{~m}, 2 \mathrm{H}), 3.58-3.28(\mathrm{~m}$, 2H), 0.20, 0.12, 0.05. 0.00 (s each, 9H); CIMS: $\mathrm{m} / \mathrm{z}$ (relative \%) 257 (25, $\mathrm{MH}^{+}-\mathrm{Me}_{2} \mathrm{SiCH}_{2}$ ), 210 (100), 144 (59), 126 (63). 
Anal. Calcd. for $\mathrm{C}_{12} \mathrm{H}_{20} \mathrm{~N}_{4} \mathrm{O}_{5} \mathrm{Si}$ : C, 43.89; H, 6.14; N, 17.06. Found: C, 43.81; H, 6.01; N, 16.77.

The filtrate was concentrated to leave $c a .30 \mathrm{~g}$ of a viscous oil that was dissolved in $100 \mathrm{~mL}$ of 1:1 ethyl acetate:cyclohexane. The solution was purified by silica gel chromatography eluting with 1:1 ethyl acetate:cyclohexane until pure product appeared, and then with $c a .3 \mathrm{~L}$ of 2:1 ethyl acetate:cyclohexane. Pure product fractions were combined and concentrated to leave $13 \mathrm{~g}$ of a solid that was triturated in 1:1 diethyl ether:ethyl acetate, collected, and dried to provide $5.67 \mathrm{~g}(8 \%)$ of a second crop of 10, mp $95-98^{\circ} \mathrm{C}$.

(R)-3-[3-(2-Nitro-1H-imidazol-1-yl)-2-[(trimethylsilyl)oxy]propyl]-2-oxazolidinone was obtained in a similar manner from (R)-9; mp 98-100 ${ }^{\circ} \mathrm{C} ;[\alpha]_{\mathrm{D}}{ }^{25}-14.54^{\circ}[\mathrm{c} 1$, methanol].

(S)-3-[2-Hydroxy-3-(2-nitro-1H-imidazol-1-yl)propyl]-2-oxazolidinone (6b).

A solution of $10.51 \mathrm{~g}(32 \mathrm{mmol})$ of $(S)$-3-[3-(2-nitro-1H-imidazol-1-yl)-2-[(trimethylsilyl)oxy]propyl]-2-oxazolidinone (10) and $32 \mathrm{~mL}$ of 1:1 methanol:glacial acetic acid was stirred at 25 ${ }^{\circ} \mathrm{C}$ for $16 \mathrm{~h}$ during which a precipitate formed. The suspension was diluted with $30 \mathrm{~mL}$ of ethanol, and the solids were collected, washed with ethanol, and dried to give $6.49 \mathrm{~g}(79 \%)$ of $\mathbf{6 b}$ as a white solid, mp $134-136{ }^{\circ} \mathrm{C}$ (lit. [8] 216-218 ${ }^{\circ} \mathrm{C}$ on racemate), $99 \%$ chemically pure (system $\mathrm{C} 2 \mathrm{~b}$ ) and $100 \%$ optically pure (system D4f) by HPLC; $[\alpha]_{\mathrm{D}}{ }^{25}-5.97^{\circ}[\mathrm{c} 1$, methanol]; ${ }^{1} \mathrm{H}$ NMR (DMSO- $\left.d_{6}\right): \delta 7.61(\mathrm{~s}, 1 \mathrm{H}), 7.17(\mathrm{~s}, 1 \mathrm{H})$, $5.44\left(\mathrm{~d}, J=5.5 \mathrm{~Hz}, 1 \mathrm{H}, \mathrm{D}_{2} \mathrm{O}\right.$ exchangeable) $4.55(\mathrm{dd}, J=13.6$ $\mathrm{Hz}, 3.5 \mathrm{~Hz}, 1 \mathrm{H})$ ), $4.30-4.18(\mathrm{~m}, 3 \mathrm{H}), 4.05-3.90(\mathrm{~m}, 1 \mathrm{H})$, $3.62(\mathrm{t}, \mathrm{J}=8.3 \mathrm{~Hz}, 2 \mathrm{H}), 3.26-3.12(\mathrm{~m}, 2 \mathrm{H})$; CIMS: $\mathrm{m} / \mathrm{z}$ (relative \%) $257\left(6, \mathrm{MH}^{+}\right), 210$ (37), 144 (27), 126 (20).

Anal. Calcd. for $\mathrm{C}_{9} \mathrm{H}_{12} \mathrm{~N}_{4} \mathrm{O}_{5}$ : C, 42.19; H, 4.72; N, 21.87 . Found: C, 42.24; H, 4.69; N, 21.85.

The filtrate was concentrated to near dryness and the solids were dissolved in methanol. The solution was decolorized with charcoal, and then filtered through a pad of silica gel. The filtrate volume was reduced to $20 \mathrm{~mL}$ and the solution was refrigerated overnight. The solids were collected and then recrystallized from $c a$. $10 \mathrm{~mL}$ of methanol. The solution was refrigerated and the formed precipitate was collected as above to provide a second crop of $\mathbf{6 b}$ as a light yellow solid, mp 134-136 ${ }^{\circ} \mathrm{C}$. The combined filtrates from the above two crystallizations were concentrated to a solid that was crystallized from methanol as above to give a third crop of $\mathbf{6 b}, \mathrm{mp} 134-136{ }^{\circ} \mathrm{C}$. The second and third crops were combined and dried to leave $1.18 \mathrm{~g}(14 \%)$ of $\mathbf{6 b}, 100 \%$ optically pure by chiral HPLC; $[\alpha]_{\mathrm{D}}{ }^{25}-5.92^{\circ}[\mathrm{c} 1$, methanol].

(R)-3-[2-Hydroxy-3-(2-nitro-1H-imidazol-1-yl)propyl]-2-oxazolidinone was obtained in a similar manner from $(R)-\mathbf{1 0}$; $\mathrm{mp}$ $136-137^{\circ} \mathrm{C} ;[\alpha]_{\mathrm{D}}{ }^{25}+5.80^{\circ}[\mathrm{c} 1$, methanol $]$.

(R)- $\alpha$-[[(2-Bromoethyl)amino]methyl]-2-nitro-1H-imidazole-1ethanol, monohydrobromide (2b; PD-144872).

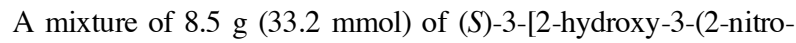
$1 H$-imidazol-1-yl)propyl]-2-oxazolidinone $(\mathbf{6 b})$ and $51 \mathrm{~mL}$ of $31 \%$ hydrogen bromide in acetic acid was stirred at $25^{\circ} \mathrm{C}$ for $7 \mathrm{~d}$. The precipitated solids were collected, washed successively with $70 \mathrm{~mL}$ of 2:1 diethyl ether:2-propanol and then $100 \mathrm{~mL}$ of diethyl ether, and air dried to leave $11.8 \mathrm{~g}$ of $\mathbf{2 b}, \mathrm{mp} 149-151{ }^{\circ} \mathrm{C}$ (dec). The product was dissolved in $100 \mathrm{~mL}$ of hot methanol, the solution was filtered through Celite, and the filtrate was stored at $25{ }^{\circ} \mathrm{C}$ for $6 \mathrm{~h}$ and then at $0-5{ }^{\circ} \mathrm{C}$ for $8 \mathrm{~h}$. The solids were collected, washed with $30 \mathrm{~mL}$ of 1:1 diethyl ether:methanol, and dried at $55^{\circ} \mathrm{C} / 150 \mathrm{~mm} / 15$ $\mathrm{h}$ to leave $7 \mathrm{~g}(56 \%)$ of $\mathbf{2 b}$ as the monohydrobromide salt, mp 154$156{ }^{\circ} \mathrm{C}$ (dec) (lit. [11] mp $149-150.5{ }^{\circ} \mathrm{C}$ ); $2 \mathbf{b}$ was $99 \%$ chemically pure (system B3b) and $100 \%$ optically pure (system E4g) by HPLC. Chiral HPLC analyses were done on $0.2 \mathrm{mg} / \mathrm{ml}$ solutions of the preformed aziridine $\mathbf{1 b}$ made by storage of $\mathbf{2 b}$ in ethanol/3 equivalents triethylamine at $25{ }^{\circ} \mathrm{C}$ for a minimum of $8 \mathrm{~h} . R_{\mathrm{t}}=c a .17 \mathrm{~min}$ for chiral analysis; $[\alpha]_{\mathrm{D}}{ }^{25}+5.57^{\circ}\left[\mathrm{c} 1\right.$, methanol]; ${ }^{1} \mathrm{H}$ NMR (DMSO- $d_{6}$ ): $\delta 8.78$ (br s, $2 \mathrm{H}, \mathrm{D}_{2} \mathrm{O}$ exchangeable), $7.63(\mathrm{~s}, 1 \mathrm{H}), 7.21(\mathrm{~s}, 1 \mathrm{H}), 5.94$ (d, $J=5.4 \mathrm{~Hz}, 1 \mathrm{H}, \mathrm{D}_{2} \mathrm{O}$ exchangeable) $4.55(\mathrm{dd}, J=13.5 \mathrm{~Hz}, 4.0$ $\mathrm{Hz}, 1 \mathrm{H}), 4.35(\mathrm{dd}, J=13.5 \mathrm{~Hz}, 7.8 \mathrm{~Hz}, 1 \mathrm{H}), 4.30-4.17(\mathrm{~m}, 1 \mathrm{H})$, $3.78-3.60(\mathrm{~m}, 2 \mathrm{H}), 3.50-3.32(\mathrm{~m}, 2 \mathrm{H}), 3.27-3.08(\mathrm{~m}, 1 \mathrm{H}), 3.02$ $-2.82(\mathrm{~m}, 1 \mathrm{H}) ;{ }^{13} \mathrm{C}$ NMR (DMSO- $\left.d_{6}\right): \delta 144.78,128.47,127.51$, 64.93, 52.22, 49.25, 47.97, 26.02; CIMS: $\mathrm{m} / \mathrm{z}$ (relative \%) 295 (5, $\left.{ }^{81} \mathrm{Br} \mathrm{MH}^{+}\right), 293\left(5,{ }^{79} \mathrm{Br} \mathrm{MH}^{+}\right), 248\left(25,{ }^{81} \mathrm{Br} \mathrm{MH}^{+}-\mathrm{HNO}_{2}\right), 246(25$, ${ }^{79} \mathrm{Br} \mathrm{MH}^{+}-\mathrm{HNO}_{2}$ ), 213 (21), 183 (23), 166 (100).

Anal. Calcd. for $\mathrm{C}_{8} \mathrm{H}_{13} \mathrm{BrN}_{4} \mathrm{O}_{3} \cdot \mathrm{HBr}: \quad \mathrm{C}, 25.69 ; \mathrm{H}, 3.77 ; \mathrm{N}$, 14.98; $\mathrm{Br}$ (tot), 42.73. Found: C, 25.40; H, 3.84; N, 14.58; Br (tot), 42.61 .

Alternatively, to a stirring ice-cold solution of $160 \mathrm{~mL}$ of $31 \%$ hydrogen bromide in acetic acid was added $31.2 \mathrm{~g}(95 \mathrm{mmol})$ of (S)-3-[3-(2-nitro-1H-imidazol-1-yl)-2-[(trimethylsilyl)oxy]propyl]-2-oxazolidinone (10), and the solution was slowly warmed to $25{ }^{\circ} \mathrm{C}$ where it was maintained for $23.5 \mathrm{~h}$. The solids were collected, washed with $100 \mathrm{~mL}$ of 2:1 diethyl ether:2-propanol, and dried to leave $28.85 \mathrm{~g}$ of a first crop of $\mathbf{2 b}$. The filtrate was poured slowly into a rapidly stirring solution of $1.2 \mathrm{~L}$ of $2: 1$ diethyl ether:2-propanol. The precipitated solids were collected, washed with $\mathrm{ca} .200 \mathrm{~mL}$ of 2:1 diethyl ether:2-propanol, and then dissolved in $80 \mathrm{~mL}$ of a $1: 1(\mathrm{v} / \mathrm{v})$ solution of $31 \%$ hydrogen bromide in acetic acid:2-propanol. The solution was stirred at $25^{\circ} \mathrm{C}$ for $24 \mathrm{~h}$ and the solids were collected and then processed as above to leave $5.35 \mathrm{~g}$ of a second crop of $\mathbf{2 b}$. The crops were combined and dissolved in $280 \mathrm{~mL}$ of hot methanol. The solution was maintained at $25^{\circ} \mathrm{C}$ for $2 \mathrm{~h}$, and then refrigerated for $4 \mathrm{~h}$. The solids were collected, washed with methanol, and dried to leave $17.62 \mathrm{~g}(50 \%)$ of analytically pure $\mathbf{2 b}$ as the monohydrobromide salt, $\mathrm{mp} 157-159{ }^{\circ} \mathrm{C}(\mathrm{dec}) ;[\alpha]_{\mathrm{D}}{ }^{25}+5.55^{\circ}$ [c1, methanol]; $\mathbf{2 b}$ was $99 \%$ chemically pure and $100 \%$ optically pure by HPLC. The methanolic filtrate was concentrated to a solid that was crystallized from $c a .60 \mathrm{~mL}$ of methanol as above to leave $3.8 \mathrm{~g}$ of another crop of $\mathbf{2 b}, \mathrm{mp} 152-154{ }^{\circ} \mathrm{C}$ (dec). Further processing of the filtrate from this crop afforded two additional crops (1.5 g and $0.5 \mathrm{~g}$ ) of $\mathbf{2 b}, \mathrm{mp} 145-150{ }^{\circ} \mathrm{C}(\mathrm{dec})$. These latter three crops were combined and recrystallized from $60 \mathrm{~mL}$ of hot methanol, with cooling at $-20{ }^{\circ} \mathrm{C}$ for $7 \mathrm{~h}$. Further processing as above gave $4.59 \mathrm{~g}(13 \%)$ of chemically and optically pure $2 \mathbf{b} ;[\alpha]_{\mathrm{D}}{ }^{25}+5.71^{\circ}$ [c1, methanol].

(S)- $\alpha$-[[(2-Bromoethyl)amino]methyl]-2-nitro- $1 H$-imidazole1-ethanol, monohydrobromide (2c; PD-144871) was obtained in a similar manner from $(R)-\mathbf{1 0}$; $\mathrm{mp} 154-155.5^{\circ} \mathrm{C}$ (dec) (lit. [11] $\left.148-149{ }^{\circ} \mathrm{C}\right) ;[\alpha]_{\mathrm{D}}{ }^{25}-6.94^{\circ}$ (c1, methanol); $R_{\mathrm{t}}$ (optical purity; preconversion to aziridine $\mathbf{1 c})=c a .13 \mathrm{~min}$.

\section{REFERENCES AND NOTES}

[*] Corresponding author; Email: showalh@umich.edu; Tel: 1734-764-5504; Fax: 1-734-647-8430. 

and A. Michel

[\#] Current address: College of Pharmacy, University of Michigan, Ann Arbor, MI 48109-1065

[§] Current address: Aureus Pharma, 75010 Paris, France; Tel: +33 (0) $14018 \quad 57$ 57; Fax: +33 (0) 1401857 58; Email andre.michel@aureus-pharma.com

[1a] H. Blaschko, Brit. Med. Bull., 29, 105 (1973); [b] A. A Khalil, S. M. Bentzen, and J. Overgaard, Int. J. Radiat. Oncol. Biol. Phys., 39, 797 (1997).

[2] T. H. Wasserman and J. D. Chapman In: Principles and Practice of Radiation Oncology; C. A. Perez and L. W. Brady, Eds.; Lippincott-Williams and Wilkins, Philadelphia, 2004, pp 663-679.

[3] D. K. Acharya, Indian J. Med. Sci., 48, 111 (1994).

[4] M. Huncharek, Anticancer Res., 18, 1935 (1998).

[5] C.-Z. Jin, H. Nagasawa, M. Shimamura, Y. Uto, S. Inayama, Y. Takeuchi, K. L. Kirk, and H. Hori, Biorg. Med. Chem., 12, 4917 (2004).

[6] K. Tanabe, R. Kojima, H. Hatta, and S. Nishimoto, Biorg. Med. Chem. Lett., 14, 2633 (2004).

[7] J. C. M. Bremmer, Cancer \& Metastasis Rev., 12, 177 (1993).

[8] M. J. Suto, M. A. Stier, and L. M. Werbel, J. Med. Chem., 34, 1207 (1991).

[9] S. Cole, I. J. Stratford, E. M. Fielden, G. E. Adams, W. Leopold, W. Elliott, M. Suto, and J. Sebolt-Leopold, Int. J. Rad. Oncol., Biol., Phys., 22, 545 (1992).

[10] V. G. Beylin, A. D. Sercel, H. D. H. Showalter, G. E. Adams E. M. Fielden, M. A. Naylor, and I. J. Stratford, United States Patent 5,543,527 (1996)
[11] M. A. Naylor, M. D. Threadgill, H. D. H. Showalter, I. J. Stratford, M. A. Stephens, E. M. Fielden, and G. E. Adams, Drug Des. Discov., 10, 249 (1993).

[12] M. J. Suto, United States Patent 4,954,515 (1990).

[13] J. M. Klunder, T. Onami, and K. B. Sharpless, J. Org. Chem., 54, 1295 (1989).

[14] J. A. Thompson, J. L. Holtzman, M. Tsuru, C. L. Lerman, and J. L. Holtzman, J. Chromatography, 238, 470 (1982).

[15] M. Hoffer and E. Grunberg, J. Med. Chem., 17, 1019 (1974).

[16a] D. E. McClure, B. H. Arison, and J. J. Baldwin, J. Am. Chem. Soc., 101, 3666 (1979); [b] K. Kawamura, T. Ohta, and G. Otani, Chem. Pharm. Bull., 38, 2092 (1990); [c] T. Fujioka, S. Teramoto, S. Tsujimi, K. Takemoto, T. Mori, T. Hosokawa, T. Sumida, M. Tominaga, and Y. Yabuuchi. Chem. Pharm. Bull., 44, 1596 (1996).

[17] T. C. Jenkins, M. A. Naylor, P. O'Neill, M. D. Threadgill, S. Cole, I. J. Stratford, G. E. Adams, E. M. Fielden, M. J. Suto, and M. A. Stier, J. Med. Chem., 33, 2603 (1990).

[18] J. M. Aizpurua, C. Palomo, and A. L. Palomo, Can. J. Chem., 62, 336 (1984)

[19] E. D. Laganis and B. L. Chenard, Tetrahedron Lett., 25, 5831 (1984).

[20] H. W. Pinnick, B. S. Bal, and N. H. Lajis, Tetrahedron Lett., 4261 (1978).

[21] All inquiries regarding X-ray data of $\mathbf{2 b}$ should be directed to A. Michel.

[22] For a more complete discussion, see chapter 4 In: Stereochemistry of Carbon Compounds, E. L. Eliel, Ed., New York:McGraw-Hill, 1962, pp 31-85. 